\title{
Assessing Profitability, Marketing Activities and Problems in Modern Rice Production in Two Northern Districts of Bangladesh
}

\author{
A. H. Siddiquee ${ }^{1}$, H. M. Sammy ${ }^{2}$ and M. R. Hasan ${ }^{1}$ * \\ ${ }^{I}$ Department of Agribusiness and Marketing and ${ }^{2}$ Department of Agricultural Statistics, Sher-e-Bangla \\ Agricultural University, Dhaka, Bangladesh \\ *Corresponding author and Email: rashidul_prince@yahoo.com
}

Received: 14 February 2019

Accepted: 09 November 2019

\begin{abstract}
This study estimated the cost and revenue of BRRI dhan 28 productions in two districts namely, Bogura and Gaibandha in Bangladesh. The paper also identifies farmers marketing activity and their production problems. Primary data were collected from 60 farm household's survey using pretested semi-structured questionnaire during November to December, 2017. Farm level production and profitability were analysed by using net farm incomes and Benefit Cost Ratio (BCR) taking into account the variable cost and total cost. Applying descriptive statistics, the analysis showed that total cost of paddy production was higher in Bogura (BDT 44,555.3/acre) compared that of Gaibandha (BDT 42,199.5/acre) while net farm income was higher in Gaibandha (BDT 32992.2/acre) than Bogura (BDT 32475.9/acre). The analysis further showed that paddy production was profitable in both districts. BCR on the basis of variable cost and total cost indicated that return from paddy production was higher than cost which also ensures farmers profit in paddy production in both the districts. According to farmers' opinion, disease infestation was the major production problem in Bogura district while both disease attack and natural calamities were the major production problems in Gaibandha district. Farmers' suggested to reduce the cost of pesticides and they need marketing facilities to sell their product. They also suggested to establish cold storage facilities which create the opportunity to get fair price for their product.
\end{abstract}

Keywords: Benefit cost ratio (BCR), gross margin, marketing activities, production problems, profitability.

\section{Introduction}

Bangladesh is an agrarian country. Rice is the staple food for 160.8 million people of the country (SVRS, 2016). The growth rate is $1.37 \%$ per year (SVRS, 2016) and an increase in total rice production is required to feed this increasing population. At the same time, the total cultivable land is decreasing day by day owing to the construction of industries, factories, houses, roads, and highways which will be the central problem in the coming years in Bangladesh. There are three rice growing seasons in Bangladesh and these are Aus, Aman and Boro season. About $58 \%$ of the people live in rural areas, and most of the people are involved in agriculture (SVRS, 2016). In Bangladesh, agriculture contributes $14.79 \%$ of the gross domestic product (GDP) (Bangladesh Economic Review, 2017). Paddy is grown throughout the 
country except in the south eastern hilly areas. The agro climatic conditions of the country are suitable for growing paddy year-round. Bangladesh ranks fourth among the paddy producing countries in the world after China, India and Indonesia (Food and Agriculture Organization of the United Nations, 2017).

In the period of 2017-2018, total area of paddy production of Bangladesh in Aus, Aman and Boro seasons were 1075.1, 5679.5 and 4859.4 thousand hectares and total paddy production of Bangladesh in Aus, Aman and Boro seasons were $2,709.7,13,993.8$ and $19,575.8$ thousand ton respectively (Bangladesh Rice Research Institute, 2018). According to the Yearbook of Agricultural Statistics of Bangladesh, (2017), Bogura district was $7^{\text {th }}$ and Gaibandha district was $15^{\text {th }}$ position in rice producing among different districts in Bangladesh. In fact those two districts are famous for rice production. Most of the farmers in the study areas produced BRRI Dhan 28 in Boro seasons. In the year 2016-2017, total production of paddy in Bogura and Gaibandha district were 702,727 M.T and 467,756 M.T respectively (Year book of Agricultural Statistics of Bangladesh, 2017). Evidence showed that the productivity and production of paddy have increased in the year 2015-2016 compared with 2013-2014. The area under paddy production was 28,101 thousand acres with an average yield of $1,222 \mathrm{~kg} /$ acre in 2013-2014; whereas the area under paddy production was 28,124 thousand acres with an average yield of 1,234 kg/acre in 2015-2016 (Year book of Agricultural Statistics of Bangladesh, 2017).

There are some studies about the profitability of paddy production in Bangladesh (Khan, 2005; Mondal, 2005; Banu, 2011; Islam, 2012; Sultana, 2017; Farzana, 2018 and Tasnoova et al. 2006). However, there are very little study about profitability of paddy production in the study area. Therefore, the present study is important for the farmer's point of view to estimate their cost and revenue of paddy production. The study not only analyses the profitability but also highlights farmers' problems and their suggestions about paddy production and marketing. The results of the study will be helpful to the policy makers to formulate future policy considering farmers production problem and the researcher for further study about modern Boro rice production and marketing. The specific objectives of the study were as follows:

- To assess the socio economic structure of the paddy farmers in the study areas.

- To verify the cost and revenue situations of the modern Boro rice producing farms.

- To identify marketing activities of the paddy farmers in the sample areas.

- To identify the problems faced by the farmers and possible solutions as proposed by the farmers under study.

\section{Methodology}

\subsection{Study area and sampling}

The present study was conducted in two paddy producing districts namely: Bogura and Gaibandha, considering that Bogura and Gaibandha districts are famous for rice production. These two districts were purposively selected. In the Boro season, farmers produced BRRI dhan 28 in both districts and therefore, BRRI dhan 28 producing farmers were selected for the present study. Purposive sampling technique was followed for data collection. A total of 60 farmers were purposively selected for the study. Among them 40 farmers from Bogura and 20 farmers from Gaibandha district were selected.

\subsection{Data collection}

Primary data were used for this study. As such, sample survey was done. A semi-structured pretested interview schedule was used for collecting data. Data were collected from the paddy farmers during November to December, 2017.

\subsection{Analytical techniques}

The revenues and costs of modern variety production were calculated. The profitability of paddy production was calculated by the 
following indices. These indices were previously used by Hasan et al. 2014, Hasan et al. (2016 a), and Hasan et al. (2016 b).

- Total variable cost $=$ Seed cost + Power tiller cost + Labor cost + Fertilizer cost + Pesticides cost + Irrigation cost.

- Total Fixed cost= Land use cost + Interest on operating capital

- Total cost $($ full cost $)=$ Total variable cost + Total fixed cost

- Gross Margin = Total revenue - Total variable cost

- Net farm income $=$ Total revenue - Total cost

- Benefit cost ratio (on variable cost) $=$

Total revenue

Total variable cost

- Benefit cost ratio (on total cost) =

Total revenue

Total cost

The issue of fund is one of the main constraints, and also one of the important components of production costs in some farmers in Bangladesh. The interest rate therefore becomes an undeniable issue in the evaluation of profitability of paddy production. The interest on operating capital was calculated for five months considering $14 \%$ interest rate in the study areas. Farmers were asked to provide their opinions about the sixteen selected problems. Problems were ranked on the basis of farmers responses. Farmer's suggestions were also included according to their opinion.

\section{Results and Discussion}

\subsection{Socioeconomic profile of the respondent farmers}

Data in table 1 show farmer's family member statistics, land use pattern and other social and economic characteristics in the study areas. Farmer's average age in Bogura district was 45.7 years and 45.3 years in Gaibandha district. Farmer's years of schooling were 7.6 in Bogura which is higher than Gaibandha district (5.2). The average number of family member in Bogura district was 5.7 and 4.5 in Gaibandha district. The national average household size is 4.4. In terms of that, the size of family in both districts was higher than national average (Statistical Pocket Book Bangladesh, 2016). In Bogura district, the average land was 0.1 acre and average cultivable land was 0.2 acre. In Gaibandha district, farmers' average own land was 0.1 acre and cultivable land was 0.1 acre. The national average operated land per farm holding was 1.48 acres and national average cultivated land per farm holdings was 1.26 acres. In terms of that, the farmers' operated own land and cultivated land was lower than national average (Statistical Pocket Book Bangladesh, 2016). In Bogura district, on average farmers have 0.03 acre of rented land, while land under and paddy production was 0.2 acre.

In Gaibandha district, average rented land was 0.04 acre and paddy production land was 0.1 acre in the same district. Average numbers of agricultural training received was 3.7 in Bogura district whereas 2.9 in Gaibandha district. Farmer's agricultural training was higher in Bogura district. Farmers' average numbers of contact with extension worker was 2.2 per year in Bogura whereas 1.5 per year in Gaibandha district. In Bogura district, farmers average farming experience were 16.9 years and 17.9 years in Gaibandha district. It is evident that farmers had long experience of rice farming in both districts. Total annual incomes of the sample households were higher in Bogura district (BDT 1, 23,220) than Gaibandha district (BDT 1, 11,780).

\subsection{Costs of paddy production in the study areas}

Data in table 2 show the costs of the paddy production in the study areas. The costs of home supplied seed were determined at the ongoing market rate in the study areas. Seed cost per acre in Bogura district was BDT 778 which was $1.7 \%$ of total costs whereas it was BDT 693 in Gaibandha district which was $1.6 \%$ of total 
costs. Power tiller cost in the Bogura district was BDT 2,943 per acre which was $6.61 \%$ of the total costs and BDT 2,825 in Gaibandha district which was $6.7 \%$ of total costs. Average labor cost per acre in the Bogura was BDT 10,780 which was $24.2 \%$ of total costs whereas BDT 11,060 in Gaibandha district which was $26.2 \%$ of total costs. The result showed that labor cost was higher in Gaibandha than Bogura district.

Farmer used four kinds of fertilizers namely Urea, Triple Super Phosphate (TSP), Muriate of Potash (MP) and Gypsum in the study areas. Farmers also used organic fertilizers such as compost. On an average, total cost of fertilizer per acre were BDT 4,621 and BDT 4,507 in Bogura and Gaibandha district respectively. Paddy growers used insecticides to protect their crop from the attack of pest and diseases. They used insecticides like Diazinon, Furadon, Bashudin, Dimecron etc. In Bogura district, total cost of pesticides was BDT 5,693 per acre which was $12.8 \%$ of total cost whereas BDT 5,750 in Gaibandha district which was $13.6 \%$ of total cost. Farmers used shallow tube well (STW) for irrigation. Irrigation cost differed across land quality. Costs of irrigation of the farmers were
BDT 3,364 and BDT 3,606 in Bogura and Gaibandha district respectively. Interest on operating capital was BDT 845 and BDT 556 in Bogura and Gaibandha district respectively in a season. Land use cost was calculated on the basis of cash rental value of per acre land for the cropping period of five months. Average land use cost per acre in a season in Bogura district was BDT 15,530 which was $34.9 \%$ of total cost whereas BDT 13,200 in Gaibandha district which was $31.3 \%$ of total cost. Total paddy production cost per acre in Bogura and Gaibandha district were BDT 44,555 and BDT 42,199 respectively. It was revealed that total cost of paddy production was higher in Bogura than Gaibandha district. Some previous studies were done about BRRI dhan 28 production. Banu (2011) found that total cost of BRRI dhan 28 production was BDT 37504.06 in Kurigram district. Islam (2012) found that total cost of BRRI dhan 28 production was BDT 36666.39 in Faridpur district. Sultana (2017) found that total cost of BRRI dhan 28 production was BDT 35339.92 in Tangail district. Farzana (2018) found that total cost of BRRI dhan 28 production was BDT 35375.81 in Mymensingh district.

Table 1. Socioeconomic profile of the sample farmers in the study areas

\begin{tabular}{|c|c|c|}
\hline Particulars & $\begin{array}{c}\text { Bogura district } \\
(\mathrm{N}=\mathbf{4 0})\end{array}$ & $\begin{array}{c}\text { Gaibandha district } \\
(\mathrm{N}=\mathbf{2 0})\end{array}$ \\
\hline \multicolumn{3}{|l|}{ 1. Family member statistics } \\
\hline Farmer's age (years) & 45.7 & 48.3 \\
\hline Farmer's years of schooling & 7.6 & 5.2 \\
\hline Total family members (no.) & 5.7 & 4.5 \\
\hline \multicolumn{3}{|l|}{ 2. Land use pattern (acre) } \\
\hline Own land & 0.1 & 0.1 \\
\hline Own cultivable land & 0.2 & 0.1 \\
\hline Rented in land & 0.03 & 0.04 \\
\hline Paddy production land & 0.2 & 0.1 \\
\hline \multicolumn{3}{|l|}{ 3. Social \& economic characteristics } \\
\hline No. of agricultural training received (life time) & 3.7 & 2.9 \\
\hline No. of extension contact (per year) & 2.2 & 1.5 \\
\hline Farming experience (year) & 16.9 & 17.9 \\
\hline Total income of the farmers (BDT) & $1,23,220$ & $1,11,780$ \\
\hline
\end{tabular}

Source: Household survey, 2017 
Table 2. Structure of cost of modern variety boro paddy production in the study areas

\begin{tabular}{|c|c|c|c|c|c|}
\hline \multirow{2}{*}{$\begin{array}{l}\text { Sl. } \\
\text { No. }\end{array}$} & \multirow[b]{2}{*}{ Cost items } & \multicolumn{2}{|c|}{$\begin{array}{l}\text { Bogura district } \\
(\mathrm{N}=\mathbf{4 0})\end{array}$} & \multicolumn{2}{|c|}{$\begin{array}{l}\text { Gaibandha district } \\
(\mathbf{N}=20)\end{array}$} \\
\hline & & $\begin{array}{l}\text { Total cost } \\
\text { (BDT/acre) }\end{array}$ & $\%$ & $\begin{array}{c}\text { Total cost } \\
\text { (BDT/acre) }\end{array}$ & $\%$ \\
\hline 1 & Seed & 778.4 & 1.7 & 693.2 & 1.6 \\
\hline 2 & Power tillers & $2,943.2$ & 6.6 & $2,825.8$ & 6.7 \\
\hline 3 & Labor & $10,780.3$ & 24.2 & $11,060.6$ & 26.2 \\
\hline 4 & Chemical and organic fertilizer & $4,621.2$ & 10.4 & $4,507.6$ & 10.7 \\
\hline 5 & Pesticides & $5,693.2$ & 12.8 & $5,750.0$ & 13.6 \\
\hline 6 & Irrigation & $3,363.6$ & 7.5 & $3,606.1$ & 8.5 \\
\hline \multicolumn{2}{|c|}{ Total variable cost } & $28,179.9$ & 63.2 & $28,443.2$ & 67.4 \\
\hline 7 & land rent per season & $15,530.0$ & 34.9 & $13,200.0$ & 31.3 \\
\hline 8 & Interest on operating capital & 845.4 & 1.9 & 556.3 & 1.3 \\
\hline \multicolumn{2}{|c|}{ Total fixed cost } & $16,375.4$ & 36.8 & $13,756.3$ & 32.6 \\
\hline \multicolumn{2}{|c|}{ Total cost } & $44,555.3$ & 100.0 & $42,199.5$ & 100 \\
\hline
\end{tabular}

Source: Household survey, 2017

\subsection{Profitability of paddy production}

Data in table 3 show the level of profitability in paddy production in Boro season in the study areas. Per acre paddy production in Bogura district was $2,762.0 \mathrm{~kg}$ whereas $2,769.0 \mathrm{~kg}$ in Gaibandha district. Price of paddy was BDT 25.8 per $\mathrm{kg}$ in Bogura and BDT 25.3 per $\mathrm{kg}$ in Gaibandha district. Per acre revenue of the farmers from selling paddy was BDT 71,232 in Bogura district and BDT 70,028 in Gaibandha district. Income from selling straw was BDT 5,799 per acre in Bogura district and BDT 5,163 in Gaibandha district. Per acre total revenue from modern variety boro paddy production in Bogura district was BDT 77,031 and BDT 75,191 in Gaibandha district. Gross farm income of the farmers from modern variety boro production in Bogura district was BDT 48,851 and BDT 46,748 per acre in Gaibandha district. Islam (2012) found that gross farm income for BRRI dhan 28 was BDT 40475 in Faridpur district. Sultana (2017) found that gross farm income of BRRI dhan 28 production was BDT 46580 in Tangail district. Farzana (2018) found that gross farm income of BRRI dhan 28 production was BDT 61159.79 in Mymensingh district. Farmers net farm income in modern variety boro production in Bogura district was BDT 32,476 per acre whereas BDT 32,992 in Gaibandha district. It is evident that net farm income in modern variety boro paddy production is higher in Gaibandha district than Bogura district. The reason is total cost of BRRI dhan 28 production is higher in Bogura than Gaibandha district. Islam (2012) found that net farm income for BRRI dhan 28 production in Faridpur district was Tk. 10727. Banu (2011) found that net farm income of BRRI dhan 28 production was BDT 8852.78 per acre in Kurigram district. Sultana (2017) found that net farm income of BRRI dhan 28 production was BDT 11240.92 in Tangail district. In Bogura district, BCR was 2.7 on the basis of variable cost whereas 2.6 in Gaibandha district. In Bogura district, BCR was 1.7 on the basis of total cost whereas 1.8 in Gaibandha district. It is evident from the result that, paddy production was profitable in both districts. Some previous studies were conducted about BRRI dhan 28 applying BCR technique. Banu (2011) found that BCR was 1.24 for BRRI dhan 28 production in Kurigram district. Sultana (2017) found that BCR (Undiscounted) for BRRI dhan 28 production in Tangail district was 1.31. Farzana (2018) found that BCR for BRRI dhan 28 production in Mymensingh district was 1.72. 
Table 3. Structure of production and profitability in growing modern variety boro paddy in the study areas

\begin{tabular}{lcc}
\hline Particulars & $\begin{array}{c}\text { Bogura district } \\
(\mathbf{N}=\mathbf{4 0})\end{array}$ & $\begin{array}{c}\text { Gaibandha district } \\
(\mathbf{N}=\mathbf{2 0})\end{array}$ \\
\hline Total Production (kg/acre) & $2,762.0$ & $2,769.0$ \\
Price of paddy (BDT/kg) & 25.8 & 25.3 \\
Revenues (BDT/acre) & $71,232.0$ & $70,028.0$ \\
Income from selling straw (BDT/acre) & $5,799.2$ & $5,163.6$ \\
Total Revenues (TR) (BDT/acre) & $77,031.2$ & $75,191.7$ \\
Total variable costs (TVC) (BDT/acre) & $28,179.9$ & $28,443.2$ \\
Gross farm incomes (TR - TVC) (BDT/acre) & $48,851.3$ & $46,748.5$ \\
Total costs (TC) (BDT/acre) & $44,555.3$ & $42,199.5$ \\
Net farm incomes (TR - TC) (BDT/acre) & $32,475.9$ & $32,992.2$ \\
\hline BCR (Variable cost basis) & $\mathbf{2 . 7}$ & $\mathbf{2 . 6}$ \\
\hline BCR (Total cost basis) & $\mathbf{1 . 7}$ & $\mathbf{1 . 8}$ \\
\hline
\end{tabular}

Source: Household survey, 2017

\subsection{Marketing activities of the farmers}

The marketing activities performed by the farmers in the study areas are presented in Table 4. Farmers are the producer of paddy. Traditionally they sell their paddy to the intermediaries either in the local markets or at the farm yards. In Bogura district, $10.0 \%$ farmers sold paddy to the village market, $30.0 \%$ to the Beparies, $20.0 \%$ to the Paikers, $10.0 \%$ to the Government agent and $30.0 \%$ to the rice millers. In Gaibandha district, $15.0 \%$ farmers sold paddy to the village market, $35.0 \%$ to the Beparies, $33.3 \%$ to the Paikers and $16.6 \%$ to the rice millers. Farmer stored some paddy for their own consumption and the rest of the amount of paddy they sold. In Bogura district, 7.5\% farmers sold between 1-50 mounds, $10.0 \%$ farmers sold between 51-100 mounds, 5.0\% farmers sold between 101-150 mounds, $5.0 \%$ farmers sold between 151-200 mounds and $72.5 \%$ farmers sold paddy above 200 mounds. In Gaibandha district, $5.0 \%$ farmers sold between 1-50 mounds, $10.0 \%$ farmers sold between $51-100$ mounds, $10.0 \%$ farmers sold between 101-150 mounds, $10.0 \%$ farmers sold between 151-200 mounds and $65.0 \%$ farmers sold paddy above 200 mounds. In Bogura district, about 48.0\% farmer's houses were 1 kilometer far from the market, $35.0 \%$ farmer's houses were 2.0 kilometer far, and $16.5 \%$ farmer's houses were 3.0 kilometer far from the market. In case of Gaibandha district, about 39.0\% farmer's houses were 1.0 kilometer far from the market, $28.5 \%$ farmer's houses were 2.0 kilometer far, $20.5 \%$ farmer's houses were 3.0 kilometer far and $12.0 \%$ farmer's houses were 4.0 kilometer far from the market.

Most of the farmers were access market information by mobile phone but some were access market information by visiting market, by reading local newspaper, by hearing radio and watching TV. In Bogura district, $80.0 \%$ farmers got market information by using mobile phone, $10.0 \%$ farmers visit market, $5.0 \%$ farmers hear radio and $5.0 \%$ farmers watch $\mathrm{TV}$ for collecting market information. In Gaibandha district, $75.0 \%$ farmers got marketing information by using mobile phone, $10.0 \%$ farmers visit market, and $5.0 \%$ farmers hear radio, $5.0 \%$ farmers watch TV and $5.0 \%$ farmers read local newspaper for collecting market information. The result showed that mobile phone was very popular to the farmers and they used mobile phone to market their paddy. 


\subsection{Farm level problems in paddy production in the study areas}

Farm level problems as mentioned by the farmers were ranked according to farmers' priority and the ranks of each problem in case of paddy production are presented in table 5 . In the Bogura district, disease attack ranked first which was the main problem in this district. Lack of skilled labor and natural calamities ranked second in the rank order. In Gaibandha district, both disease attack and natural calamities were mentioned by the sample farmers as the serious problems in modern variety boro paddy production. As such these two problems ranked the first since these problems hamper paddy production almost always. Lack of transportation facilities ranked second in the rank order. High price of fertilizers, unavailability of fertilizers, low price of paddy, lack of pesticide, high price of pesticides, lack of storage facility, high transportation cost and lack of credit facility were mentioned by the farmers as their problems in the study areas. The result showed that disease attack and natural calamities were very common in both districts and those two reason affected paddy production. Some previous studies were done related with BRRI dhan 28 production and the researchers found different types of production problems. Banu (2011) found that high cost of irrigation, lack of capital, high price of input, lack of market information and dominance of intermediaries were the major production problems of BRRI dhan 28 in Kurigram district.

Table 4. Scenario of marketing activities of the farmers

\begin{tabular}{|c|c|c|c|}
\hline \multirow{2}{*}{ Sl. No. } & \multirow{2}{*}{ Particulars } & \multicolumn{2}{|c|}{$\%$ farms followed } \\
\hline & & Bogura district & Gaibandha district \\
\hline \multirow[t]{6}{*}{1} & Sell of paddy & & \\
\hline & Village market & 10.0 & 15.0 \\
\hline & Bepari & 30.0 & 35.0 \\
\hline & Paikar & 20.0 & 33.3 \\
\hline & Government agent & 10.0 & 00.0 \\
\hline & rice miller & 30.0 & 16.6 \\
\hline \multirow[t]{6}{*}{2} & Amount of paddy disposed & & \\
\hline & $1-50$ mound & 07.5 & 05.0 \\
\hline & 51-100 mound & 10.0 & 10.0 \\
\hline & $101-150$ mound & 05.0 & 10.0 \\
\hline & 151-200 mound & 05.0 & 10.0 \\
\hline & More than 200 mound & 72.5 & 65.0 \\
\hline \multirow[t]{5}{*}{3} & Average distance of the market & m farmers home & \\
\hline & 1 kilometer & 48.5 & 39.0 \\
\hline & 2 kilometer & 35.0 & 28.5 \\
\hline & 3 kilometer & 16.5 & 20.5 \\
\hline & 4 kilometer & 00.0 & 12.0 \\
\hline \multirow[t]{6}{*}{4} & Access to market information & & \\
\hline & Mobile phone & 80.0 & 75.0 \\
\hline & Market visit & 10.0 & 10.0 \\
\hline & Radio & 05.0 & 05.0 \\
\hline & Television & 05.0 & 05.0 \\
\hline & Local newspaper & 00.0 & 05.0 \\
\hline
\end{tabular}

Source: household survey, 2017 
Table 5. Farmers' stated problems in paddy production in the study areas

\begin{tabular}{|c|c|c|c|c|}
\hline \multirow{2}{*}{ Stated problems } & \multicolumn{2}{|c|}{$\begin{array}{c}\text { Bogura district } \\
(\mathrm{N}=\mathbf{4 0 )}\end{array}$} & \multicolumn{2}{|c|}{$\begin{array}{c}\text { Gaibandha district } \\
(\mathbf{N}=\mathbf{2 0})\end{array}$} \\
\hline & $\begin{array}{c}\% \text { farmers } \\
\text { opined }\end{array}$ & Rank order & $\begin{array}{c}\% \text { farmers } \\
\text { opined }\end{array}$ & Rank order \\
\hline 1. Lack of quality seed & 50.0 & $7^{\text {th }}$ & 30.0 & $7^{\text {th }}$ \\
\hline 2. Lack of skilled labor & 82.5 & $2^{\text {nd }}$ & 55.0 & $5^{\text {th }}$ \\
\hline 3. Low price of paddy & 25.0 & $12^{\text {th }}$ & 30.0 & $7^{\text {th }}$ \\
\hline 4. Disease attack & 97.5 & $1^{\mathrm{st}}$ & 100.0 & $1^{\text {st }}$ \\
\hline 5. Lack of family labor & 10.0 & $14^{\text {th }}$ & 10.0 & $8^{\text {th }}$ \\
\hline 6. High price of fertilizers & 70.0 & $3^{\text {rd }}$ & 60.0 & $4^{\text {th }}$ \\
\hline 7. Unavailability of fertilizers & 27.5 & $11^{\text {th }}$ & 70.0 & $3^{\text {rd }}$ \\
\hline 8. Lack of irrigation facilities & 12.5 & $13^{\text {th }}$ & 5.0 & $9^{\text {th }}$ \\
\hline 9. Lack of transportation facilities & 30.0 & $10^{\text {th }}$ & 70.0 & $3^{\text {rd }}$ \\
\hline 10. High transportation cost & 47.5 & $8^{\text {th }}$ & 60.0 & $4^{\text {th }}$ \\
\hline 11. Lack of storage facility & 55.0 & $5^{\text {th }}$ & 80.0 & $2^{\text {nd }}$ \\
\hline 12. Climate change & 7.5 & $15^{\text {th }}$ & 0.0 & $10^{\text {th }}$ \\
\hline 13. Natural calamities & 82.5 & $2^{\text {nd }}$ & 100.0 & $1^{\mathrm{st}}$ \\
\hline 14. Lack of pesticide & 42.5 & $9^{\text {th }}$ & 55.0 & $5^{\text {th }}$ \\
\hline 15. High price of pesticides & 67.5 & $4^{\text {th }}$ & 55.0 & $5^{\text {th }}$ \\
\hline 16. Lack of credit facility & 52.5 & $6^{\text {th }}$ & 50.0 & $6^{\text {th }}$ \\
\hline
\end{tabular}

Source: household survey, 2017

Table 6. Farmers' suggestions to solve the stated problems

\begin{tabular}{lcccc}
\hline \multirow{2}{*}{$\begin{array}{l}\text { List of suggestions } \\
\text { Need good quality of seed }\end{array}$} & \multicolumn{2}{c}{ Bogura district $(\mathbf{N}=\mathbf{4 0})$} & \multicolumn{2}{c}{ Gaibandha district $(\mathbf{N}=\mathbf{2 0})$} \\
\cline { 2 - 5 } & $\begin{array}{c}\text { \% farmers } \\
\text { opined }\end{array}$ & $\begin{array}{c}\text { Rank order } \\
\text { \% farmers } \\
\text { opined }\end{array}$ & Rank order \\
\hline Need marketing facility & 55.0 & $5^{\text {th }}$ & 45.0 & $8^{\text {th }}$ \\
Training required for farmer & 82.5 & $3^{\text {rd }}$ & 95.0 & $1^{\text {st }}$ \\
Need agricultural equipments & 77.5 & $4^{\text {th }}$ & 80.0 & $4^{\text {th }}$ \\
Need storage facility & 47.5 & $7^{\text {th }}$ & 50.0 & $7^{\text {th }}$ \\
Need transport facilities & 85.0 & $2^{\text {nd }}$ & 85.0 & $3^{\text {rd }}$ \\
Reduce transportation cost & 45.0 & $8^{\text {th }}$ & 75.0 & $5^{\text {th }}$ \\
Required fertilizer at reasonable prize & 47.5 & $7^{\text {th }}$ & 85.0 & $3^{\text {rd }}$ \\
Improve irrigation facilities & 50.0 & $6^{\text {th }}$ & 55.0 & $6^{\text {th }}$ \\
Need credit facilities & 22.5 & $9^{\text {th }}$ & 15.0 & $9^{\text {th }}$ \\
Reduce the cost of pesticides & 50.0 & $6^{\text {th }}$ & 75.0 & $5^{\text {th }}$ \\
\hline
\end{tabular}

Source: household survey, 2017 
Islam (2012) found that seasonal labor shortage and high wage rate $(65 \%)$, lack of capital or institutional credit $(55 \%)$ and high price of inputs $(57 \%)$ were the major production problems of BRRI dhan 28 in Faridpur district. Sultana (2017) found that low price of rice was the major problem of farmers for BRRI dhan 28 production in Tangail district. Farzana (2018) found that lack of capital and labor crisis and high wage rate were the major production problems of BRRI dhan 28 farmers in Mymensingh district.

\subsection{Farmers' stated suggestions to solve their problems}

The sample farmers mentioned several suggestions to overcoming the common problems and those are summarized in table 6 . In Bogura district, farmers suggested minimizing the cost of pesticides and it ranked first position. Farmers need storage facility which ranked second and farmers need marketing facility to market their paddy which ranked third in Bogura district. In Gaibandha district, farmers need marketing facility which ranked first, while they suggested for reducing the cost of pesticides which ranked second. Farmers need storage facility and they also suggested minimizing transportation cost which ranked third to solve their problems in Gaibandha. They also suggested for special training, supply of good quality seed, ensuring credit facilities to increase paddy production in the study areas.

\section{Conclusions and Recommendations}

This paper analyzes the profitability of modern variety boro paddy production in Bogura and Gaibandha districts. The paper identifies different marketing activities of farmers and the study identifies different problems of the farmers related to paddy production. The findings clearly indicate that, both net farm incomes and BCR in modern variety boro paddy production were positive in the study areas although farmers face different types of problems. According to the rank order, disease attack was the main problem in both Bogura and Gaibandha district. Disease attack can be solved by using pesticides at a recommended dose at a reasonable price. Market facilities should be developed by government so that farmers sell their product easily and get better price. Government may establish more cold storage facilities which may create the opportunity to get fair price for their output. Second option is that government may buy more paddies directly from farmers at a higher price than market which will also ensure fair price for the farmers.

\section{References}

Banu B. 2011. A comparative economic analysis of BRRI dhan 28, BRRI dhan 29 and Hybrid Hira rice production in selected areas of Kurigram district, $M S$ Thesis, Department of Agricultural Economics, Bangladesh Agricultural University, Mymensingh, Bangladesh.

Bangladesh Economic Review (BER). 2017. Finance division, Ministry of Finance, Government of the People's Republic of Bangladesh, Dhaka.

Bangladesh Rice Research Institute (BRRI). 2018. Rice Database, Joydebpur, Gazipur, Bangladesh.

Farzana DN. 2018. A comparative economic study on BRRI dhan 28 and Bina dhan 5 production in selected areas of Mymensingh district. MS Thesis, Department of Agricultural Economics, Bangladesh Agricultural University, Mymensingh, Bangladesh.

Food and Agriculture Organization of the United Nations (FAO). 2017. Rice Market Monitor, Rome, Italy.

Hasan MR., HU B. 2016a. Profitability of Tomato production in three districts of Bangladesh, International Journal of BioResearch, 21(6):1-8.

Hasan MR., Mutatisse AA., Nakamoto E., HU B. 2014. Profitability of Cauliflower and Bean Production in Bangladesh -A Case 
Study in Three Districts, Bangladesh Journal of Extension Education, 26 (1\&2):63-75.

Hasan MR., HU B. 2016b. Profitability of Brinjal production in three districts of Bangladesh. Eco-friendly Agriculture Journal, 9(08):55-59.

Islam T. 2012. A comparative economic study of BRRI dhan 28 and BRRI dhan 29 rice production in selected areas of Faridpur district, MS Thesis, Department of Agricultural Economics, Bangladesh Agricultural University, Mymensingh, Bangladesh.

Khan MB. 2005. Processing of Boro paddy and its marketing in selected areas of Sherpur district. MS Thesis, Department of Cooperation and Marketing, Bangladesh Agricultural University, Mymensingh.

Mondal RK. 2005. An Economic study of input use and productivity of HYV Boro paddy producing farms by tenancy in some selected areas of Gaibandha district. $M S$ Thesis, Department of Agricultural Economics, Bangladesh Agricultural University, Mymensingh.
Sample Vital Registration System (SVRS). 2016. Bangladesh Sample Vital Statistics, Bangladesh Bureau of Statistics, Ministry of Planning, Government of the People's Republic of Bangladesh, Dhaka, 31p.

Statistical Pocket Book Bangladesh, Bangladesh Bureau of Statistics (BBS). 2016. Statistics and informatics division, Ministry of Planning, Government of the People's Republic of Bangladesh, Dhaka, $8 \mathrm{p}$.

Sultana D. 2017. A comparative economic study of BRRI dhan 28 and BRRI dhan 29 production in selected areas of Tangail district, MS Thesis, Department of Agricultural Economics, Bangladesh Agricultural University, Mymensingh, Bangladesh.

Tasnoova S., Iwamoto I. 2006. Kataribough rice marketing system in Dinajpur district of Bangladesh, Laboratory of Agricultural Marketing, Memoirs of the Faculty of Agriculture, Kagoshima University, Japan, 41, 19-50 pp.

Yearbook of Agricultural Statistics of Bangladesh. 2017. Ministry of Planning, Government of the People's Republic of Bangladesh, Dhaka. 